Article

\title{
Impacts of UV Filters in Mytilus galloprovincialis: Preliminary Data on the Acute Effects Induced by Environmentally Relevant Concentrations
}

\author{
Diana Bordalo 1미, Carla Leite ${ }^{1,2}$, Ângela Almeida ${ }^{1,2}$, Amadeu M. V. M. Soares ${ }^{1,2}$, \\ Carlo Pretti ${ }^{3,4}$ and Rosa Freitas $1,2, *$ (D) \\ 1 Department of Biology, University of Aveiro, 3810-193 Aveiro, Portugal; dianabordalo@ua.pt (D.B.); \\ carlapleite@ua.pt (C.L.); aaalmeida@ua.pt (Â.A.); asoares@ua.pt (A.M.V.M.S.) \\ 2 Centre for Environmental and Marine Studies (CESAM), University of Aveiro, 3810-193 Aveiro, Portugal \\ 3 Interuniversity Consortium of Marine Biology of Leghorn "G. Bacci”, 57128 Livorno, Italy; \\ carlo.pretti@unipi.it \\ 4 Department of Veterinary Sciences, University of Pisa, 56122 San Piero a Grado, Italy \\ * Correspondence: rosafreitas@ua.pt
}

Received: 15 June 2020; Accepted: 15 August 2020; Published: 24 August 2020

check for updates

\begin{abstract}
Ultraviolet (UV) filters are present in a broad range of personal hygiene products, which may be transported via aquatic environments and domestic wastewaters due to inefficient treating station sewage removal and direct human contact. The aim of the present study was to evaluate the potential effects of a UV filter, in particular benzophenone-3 (BP3) (also known as oxybenzone) on the mussel species Mytilus galloprovincialis. Mussels were exposed to this organic substance for $96 \mathrm{~h}$ in environmentally relevant concentrations $(10,100$, and $1000 \mathrm{ng} / \mathrm{L})$. After exposure, biomarkers related with the mussels' metabolism and oxidative stress were evaluated. The results revealed significantly higher activity of electron transport system and energy reserves (glycogen and protein (PROT)) at the intermediate concentration of $100 \mathrm{ng} / \mathrm{L}$, suggesting that at lower concentrations mussels' metabolism was not activated due to low stress. Conversely, at the highest concentration $(1000 \mathrm{ng} / \mathrm{L})$, mussels were no longer able to continue to increase their metabolic activity. Higher metabolic capacity was accompanied by increased PROT content associated with increased enzyme production to activate their antioxidant system. Nevertheless, at the highest concentration, cellular damage occurred as a consequence of ineffective activation of antioxidant and biotransformation enzymes. The results of the present study address uncertainties that are fundamental to the environmental risk assessment and management of these economically important near-shore bivalves and other marine species. Although an acute exposure was performed, alterations observed indicate the negative impacts of BP3 towards marine bivalves, which could be enhanced after longer exposure periods or if mussels are simultaneously exposed to other stressors (e.g., other pollutants or climate change related factors). The present study may thus contribute to the definition of fundamental knowledge for the establishment of appropriate regulatory guidelines and practices that ensure the preservation and sustainability of biological resources, allowing for prediction and mitigation of the impacts from these compounds.
\end{abstract}

Keywords: mussels; oxybenzone; benzophenone-3 (BP3); metabolism; oxidative stress; energy reserves

\section{Introduction}

The rising concern regarding ultraviolet (UV) rays exposure is mainly associated with the risk of developing skin cancer, erythema, and photoaging, with an increasing awareness about protecting 
human bodies with photoprotective clothing and, principally, sunscreen [1]. Sunscreens contain inorganic compounds capable of reflecting UV rays and organic compounds that reflect UV A (315 to $400 \mathrm{~nm}$ ) and UV B rays (280 to $315 \mathrm{~nm}$ ) [2,3]. Benzophenone-3 (BP3) (also known as Oxybenzone) and 2-ethylhexyl-4-methoxycinnamate are among these organic compounds. These chemicals can be found in several personal hygiene products such as face creams, shampoos, color stabilizers for lipsticks, or hair dyes, as well as in plastic mixtures and hand/dish soaps [4-6]. Personal care products containing these filters are used on a daily basis, which greatly increases the chance of these compounds to be released into domestic waters [7]. Calafat et al. [8] showed evidences that BP3 was present in $96.8 \%$ of 2517 urine samples, containing a range from 0.4 to $21.700 \mu \mathrm{g} / \mathrm{L}$. Furthermore, it has been proven that wastewater treatment plants (WWTPs) do not effectively remove compounds such as UV filters, resulting in their transportation towards aquatic systems [9-12]. Ultraviolet filters can therefore reach rivers and marine coastal areas through this route or during recreational activities, such as swimming [13]. Thus, the concentration of these compounds can gradually increase with the wider use of these products.

Benzophenone-3 is an organic UV filter with a molecular weight of $228.25 \mathrm{~g} / \mathrm{mol}$ and a solubility of $68.56 \mathrm{mg} / \mathrm{L}$ [14]. It is reported to have resistance to photodegradation and to be bioaccumulative [15]. The maximum concentrations of BP3 permitted by law in sunscreens are 10, 6 and $5 \mathrm{~g} / 100 \mathrm{~g}$ in Europe, USA and Japan, respectively [16]. However, low concentrations of these substances have been reported in coastal systems, which is the case for BP3 concentrations found in Ria de Aveiro (Portugal), ranging between 27 and $46 \mathrm{ng} / \mathrm{L}$ [9]. Benzophenone-3 was also detected in a WWTP effluent in Oslo (Norway), varying from 81 to $598 \mathrm{ng} / \mathrm{L}$ with a concentration lower than $10 \mathrm{ng} / \mathrm{g}$ (DW, dry weight) found in its sludge. In Majorca Island's (Spain), BP3 was detected in surface coastal waters at a concentration ranging from 53.6 to $577.5 \mathrm{ng} / \mathrm{L}$ [17,18]. According to Juliano and Magrini [19], the environmental concentrations of this compound depend mainly on the population of a place, investment and quality of removal on sewage treatment stations, and mostly on the season, since there are more people frequenting beaches during warmer and sunnier summer days.

Bivalves are known for bioaccumulating chemical pollutants in their soft tissues, since these are sessile filter-feeding organisms. Among bivalves, mussels are well-known bioindicator species, including Mytilus galloprovincialis, due to their wide geographical distribution and abundance [20,21]. To our knowledge, scarce information is available regarding concentration levels and effects induced in bivalves due to BP3 exposure. Vidal-Liñán et al. [22] demonstrated that M. galloprovincialis specimens accumulated low concentrations of BP3 in their soft tissues (about $80 \mu \mathrm{g} / \mathrm{kg}$ DW), which remained relatively constant along the experimental exposure period (30 days) and decreased after a 20-days depuration period. In another study, $35.4 \pm 1.5 \mathrm{ng} / \mathrm{g}$ DW of BP3 was measured in the tissues of the mussel species Ischadium recurvum [23]. He et al. [24] measured a concentration of $118.0 \mathrm{ng} / \mathrm{g}$ DW of BP3 in the oyster Crassostrea virginica and suggested a similar bioaccumulation of UV filters in shellfish.

It has been widely recognized that the accumulation of pollutants by wildlife, including marine bivalves, generates negative effects, with physiological and biochemical impairments being frequently demonstrated. Similarly, harmful effects have been described in different aquatic organisms such as fish, bivalves, and corals after exposure to UV filters [25]. In particular, studies already demonstrated that the fish species Carassius auratus exposed for 7, 14 and 28 days to the UV filters benzophenone-1, benzophenone-2, benzophenone-3, and benzophenone- 4 (at concentrations of 0.5 and $5 \mathrm{ng} / \mathrm{L}$, for each chemical compound), may increase the reactive oxygen species (ROS) production, leading to oxidative stress by altering the antioxidant defense system [26]. Kim et al. [27] observed that reproduction of the fish species Oryzias latipes decreased, having a hatchability of $88.3 \%$ following 28 days of exposure to $26 \mu \mathrm{g} / \mathrm{L}$ of BP3, affecting the endocrine balance as well. Moreover, studies with the clam species Scrobicularia plana revealed the induction of oxidative stress after exposure for 7 days to $1 \mathrm{mg} / \mathrm{L}$ of microplastics adsorbed with $82 \mathrm{ng} / \mathrm{g}$ of BP3 [28]. Zhong et al. [29] reported that concentrations as low as $22.8 \mathrm{ng} / \mathrm{L}$ of BP3 caused a significant inhibition of growth and chlorophyll synthesis of the algae Arthrospira sp. and Chlorella sp. after 20 days of exposure. The bleaching of pigment following 7 days 
of exposure to higher concentrations than $2.28 \mathrm{mg} / \mathrm{L}$ had the same result, whereas concentrations of $0.228 \mathrm{mg} / \mathrm{L}$ or higher inhibited photosynthesis as well as respiration, and led to the accumulation of ROS. Almeida et al. [30] reported effects of acute exposure (96 h) to BP3 at environmentally relevant concentrations $(10,100$, and $1000 \mathrm{ng} / \mathrm{L})$ in the fish species Poecilia reticulata, where both 100 and $1000 \mathrm{ng} / \mathrm{L}$ caused DNA damage of erythrocytes along with an increased number of nuclear abnormalities of these cells, suggesting this compound's genotoxic and mutagenic effects. Paredes et al. [31] determined the concentration of the UV filter BP3 responsible for EC50, identified as a $50 \%$ reduction in the percentage of normal D-larvae in M. galloprovincialis, which corresponded to $3472.59 \mu \mathrm{g} / \mathrm{L}$.

Therefore, considering the literature available and the lack of knowledge regarding the effects of BP3 on the biochemical performance of bivalves, especially at environmentally relevant concentrations, the present study aimed to evaluate the metabolic and oxidative stress alterations induced in the mussel M. galloprovincialis. Biological alterations were assessed after an acute exposure $(96 \mathrm{~h})$ to a range of increasing concentrations of BP3 (Control-0, 10, 100 and $1000 \mathrm{ng} / \mathrm{L}$ ). For this, mussels' energy reserves content, metabolic capacity, cellular damage, and antioxidant and biotransformation defenses were measured in mussels' whole soft tissues.

\section{Material and Methods}

\subsection{Experimental Conditions}

In September 2019, mussels of the species Mytilus galloprovincialis were collected during low tide at the Ria de Aveiro coastal lagoon (Portugal) and transported to a laboratory. In the laboratory, mussels with a similar size $(10.7 \pm 3.0 \mathrm{~g}$ fresh weight $)$ were maintained during one week in artificial seawater at $17^{\circ} \mathrm{C}$ with a salinity of 30 (prepared by mixing filtered freshwater with commercial sea salt, Tropic Marin ${ }^{\circledR}$ SEA SALT), with a 12:12 Light: Darkness photoperiod. During the first 3 days, the mussels were not fed after which it was given Algamac protein plus (150,000 cells/animal) every other day. During this period water was renewed every two days.

After acclimation, mussels were distributed in different aquaria (6 individuals per aquarium), containing $6 \mathrm{~L}$ of seawater (salinity 30 and temperature $17^{\circ} \mathrm{C}$ ). Three aquaria were used in the following conditions: control- $0 \mathrm{ng} / \mathrm{L}, 10 \mathrm{ng} / \mathrm{L}, 100 \mathrm{ng} / \mathrm{L}$, and $1000 \mathrm{ng} / \mathrm{L}$ of benzophenone-3 (BP3) and dimethyl sulfoxide (DMSO) (the solvent used to prepare BP3 stock solution). A stock solution of $1 \mathrm{mg} / \mathrm{L}$ of BP3 in DMSO (1\%) was prepared using distillated water. Benzophenone-3 used in the experiment was obtained from Sigma-Aldrich (chemical purity $\geq 98 \%$ ).

During the exposure period $(96 \mathrm{~h})$, aquaria were continuously aerated, temperature $\left(17^{\circ} \mathrm{C}\right)$ and salinity were checked daily and adjusted if necessary, and mussels were fed with Algamac protein plus (150,000 cells/animal) every other day. Mussels feces were removed when identified in the aquaria to guarantee water quality.

Mortality was checked every day and organisms were considered dead when their shells gaped and failed to shut again after external stimulus. At the end of the experiment, mussels were immediately frozen $\left(-80^{\circ} \mathrm{C}\right)$ until further analyses.

\subsection{Biochemical Markers}

Biochemical markers related with metabolic capacity, energy reserves, and oxidative stress were measured in mussels exposed to different BP3 concentrations (CTL-0, 10, 100, and $1000 \mathrm{ng} / \mathrm{L}$ of BP3) and DMSO $(\leq 0.001 \%)$. Graphical representations were obtained considering the mean and standard deviation values of the 3 aquaria/condition. From each aquarium, a mean of two mussels was used.

For biochemical analyses mussels' whole soft tissues were homogenized manually using liquid nitrogen with a mortar and pestle. Homogenized tissues were divided in different aliquots containing $0.5 \mathrm{~g}$ fresh weight (FW) to determine the following biomarkers: electron transport system activity (ETS); total protein content (PROT); glycogen content (GLY); the activity of the antioxidant and 
biotransformation enzymes catalase (CAT); glutathione peroxidase (GPx) and glutathione S-transferases (GSTs); and lipid peroxidation (LPO) levels.

Specific buffers were used depending on the biochemical parameter: (i) $20 \%(v / v)$ trichloroacetic acid solution (TCA) with a 1:2 proportion in order to extract the supernatants for the LPO assay; (ii) to extract the supernatants for PROT, GLY, GPx, GSTs, and CAT assays, it was used the potassium phosphate $50 \mathrm{mM}$ KH2PO4 (pH7.0); EDTA $1 \mathrm{mM}$, Triton X-100 1\% (v/v); PVP $1 \mathrm{mM}$ DTT) buffer; (iii) the extraction for the quantification of ETS was made with a BSS buffer, consisting of $0.13 \mathrm{M}$ Tris- $\mathrm{HCl}, 0.3 \%(v / v)$ Triton X-100 with $\mathrm{pH}$ 8.5. The samples were sonicated with a TissueLyser II with a frequency of $20 \mathrm{1} / \mathrm{s}$, for $1 \mathrm{~min}$ and $30 \mathrm{~s}$, at $4{ }^{\circ} \mathrm{C}$. After cooling down, these were centrifuged was at 10,000 g (3000 g for ETS) for $20 \mathrm{~min}$, at $4{ }^{\circ} \mathrm{C}$. Afterwards, extractions for biochemical analyses were made using a microplate reader (BioTek Synergy, Winooski, VT, USA) and the samples were preserved at a temperature of $-80^{\circ} \mathrm{C}$.

\subsubsection{Metabolic Capacity and Energy-Related Markers}

The activity of ETS was assessed following King and Packard [32] method with modifications performed by De Coen and Janssen [33]. Samples were measured at an absorbance of $490 \mathrm{~nm}$ during $10 \mathrm{~min}$ with intervals of $25 \mathrm{~s}$. For the calculation of formazan, the extinction coefficient $\varepsilon=15,900 \mathrm{M}^{-1} \mathrm{~cm}^{-1}$ was used and results were expressed in $\mathrm{nmol} / \mathrm{min} / \mathrm{g} \mathrm{FW}$.

The PROT content was determined according to the method developed by Robinson and Hodgen [34]. A BSA solution $(40 \mathrm{mg} / \mathrm{mL}$ ) was used to prepare standards ( 0 to $40 \mathrm{mg} / \mathrm{mL}$ ). The absorbance was read at $540 \mathrm{~nm}$ and the results were expressed in $\mathrm{mg} / \mathrm{g}$ FW.

The GLY content was quantified in accordance with Dubois et al. [35]. Glucose standards were prepared ( 0 to $5 \mathrm{mg} / \mathrm{mL}$ ) and the absorbance was read at $492 \mathrm{~nm}$ after incubation for $30 \mathrm{~min}$ at room temperature. Results were expressed in $\mathrm{mg} / \mathrm{g}$ FW.

\subsubsection{Oxidative Stress Markers}

The activity of CAT was determined as described by Johansson and Borg [36] with adaptations by Carregosa et al. [37], where formaldehyde was used as the standard $(0-150 \mu \mathrm{M})$. Samples were read at an absorbance of $540 \mathrm{~nm}$ and results were expressed in U/mg FW, where U represents the amount of enzyme that caused the formation of $1.0 \mathrm{nmol}$ formaldehyde per min at $25^{\circ} \mathrm{C}$.

The activity of GPx was determined following Paglia and Valentine [38]. The absorbance was measured at $340 \mathrm{~nm}$ in $10 \mathrm{~s}$ intervals during $5 \mathrm{~min}$ and the enzymatic activity was determined using $\varepsilon=6.22 \mathrm{mM}^{-1} \mathrm{~cm}^{-1}$. The results were expressed in $\mathrm{U} / \mathrm{g} \mathrm{FW}$, where $\mathrm{U}$ represents the amount of enzyme that caused the formation of $1.0 \mu \mathrm{mol}$ NADPH oxidized per min.

Following the method described in Habig et al. [39] with alterations by Carregosa et al. [37], the GSTs activity was measured at an absorbance of $340 \mathrm{~nm}$ for $5 \mathrm{~min}$ with an interval of $15 \mathrm{~s}$, using $\varepsilon=9.6 \mathrm{mM}^{-1} \mathrm{~cm}^{-1}$. The concentration was expressed in $\mathrm{U} / \mathrm{g} \mathrm{FW}$, where $\mathrm{U}$ represents the amount of enzyme that catalyzes the formation of $1 \mu \mathrm{mol}$ of dinitrophenyl thioether per min.

Following Buege and Aust [40], LPO levels were measured at an absorbance of $532 \mathrm{~nm}$, determining the content of malondialdehyde (MDA). The results were obtained using the equation $\mathrm{A}=\varepsilon \times \mathrm{b} \times \mathrm{C}$, where $\varepsilon$ corresponds to the MDA extinction coefficient $\left(\varepsilon=1.56 \times 105 \mathrm{M}^{-1} \mathrm{~cm}^{-1}\right)$, and expressed in nmol of MDA/g FW.

\subsection{Data Analyses}

The results for ETS, PROT, GLY, LPO, CAT, GPx, and GSTs were statistically verified using the routine PERMANOVA + add-on from the software PRIMER v6 [41]. The null hypothesis tested was that for each biochemical marker, no significant differences were found among conditions (CTL-0; 10, 100 and $1000 \mathrm{ng} / \mathrm{L}$ of BP3). For each biomarker in the figures, different lowercase letters represent statistical differences $(p<0.05)$ among the conditions. 


\section{Results}

\subsection{Mortality}

After the exposure period $(96 \mathrm{~h})$, no mortality was observed regardless of the condition.

\subsection{Biochemical Responses}

Since no significant differences were observed between organisms exposed to control (CTL) and DMSO conditions, results corresponding to organisms exposed to the solvent were not included in this section. Metabolic capacity, energy reserves, and oxidative stress parameters are given for each BP3 exposure concentration (CTL-0, 10, 100, and $1000 \mathrm{ng} / \mathrm{L}$ ).

\subsubsection{Metabolic Capacity and Energy-Related Markers}

The activity of ETS was significantly higher in mussels exposed to $100 \mathrm{ng} / \mathrm{L}$ of BP3 in comparison with the remaining conditions. No significant differences were observed among mussels exposed to CTL, $10 \mathrm{ng} / \mathrm{L}$ and $1000 \mathrm{ng} / \mathrm{L}$ (Figure 1A).
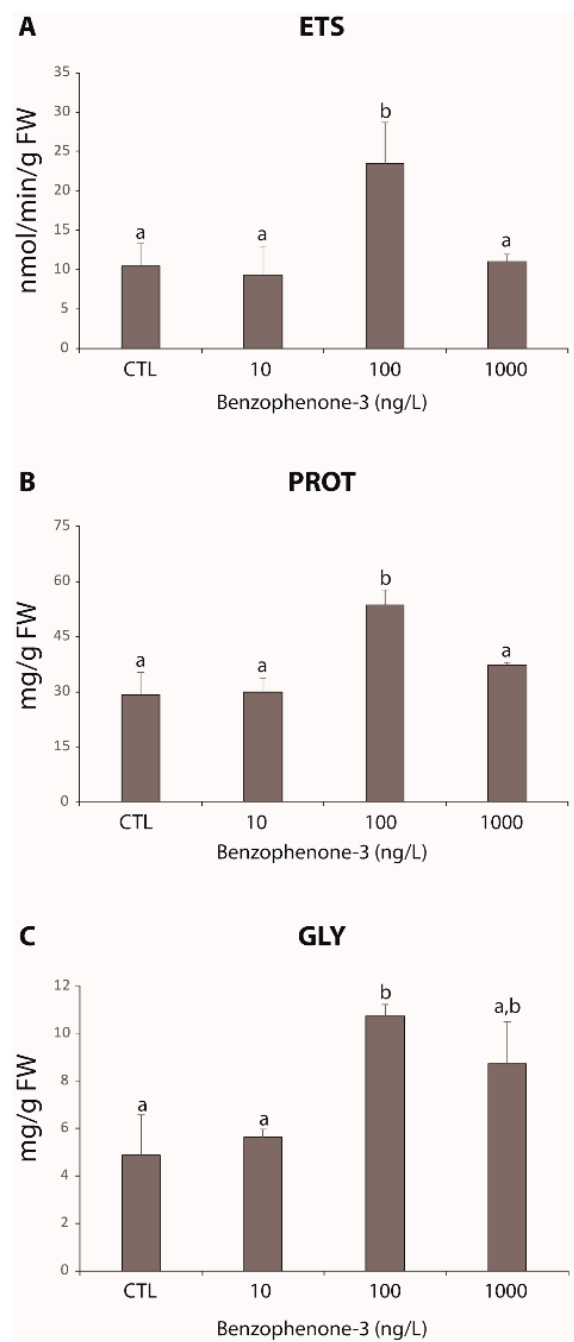

Figure 1. (A): Electron transport system activity (ETS), (B): protein content (PROT), (C): glycogen content (GLY), in Mytilus galloprovincialis exposed to different concentrations of Benzophenone-3 (CTL-0, 10, 100, and $1000 \mathrm{ng} / \mathrm{L})$, during $96 \mathrm{~h}$. Results are means with standard deviation. Different letters represent significant differences $(p<0.05)$ among concentrations. 
Similar to ETS results, the PROT content was significantly higher in mussels exposed to $100 \mathrm{ng} / \mathrm{L}$ of BP3 in comparison with the remaining conditions. No significant differences were observed among mussels exposed to CTL, $10 \mathrm{ng} / \mathrm{L}$ and $1000 \mathrm{ng} / \mathrm{L}$ (Figure 1B).

The GLY content was significantly higher in mussels exposed to $100 \mathrm{ng} / \mathrm{L}$ in comparison with CTL and $10 \mathrm{ng} / \mathrm{L}$ of BP3. No significant differences were observed among mussels exposed to CTL, $10 \mathrm{ng} / \mathrm{L}$ and $1000 \mathrm{ng} / \mathrm{L}$ (Figure 1C).

\subsubsection{Oxidative Stress Markers}

In terms of CAT and GPx activity, no significant differences were observed among the tested conditions (Figure 2A,B).

A

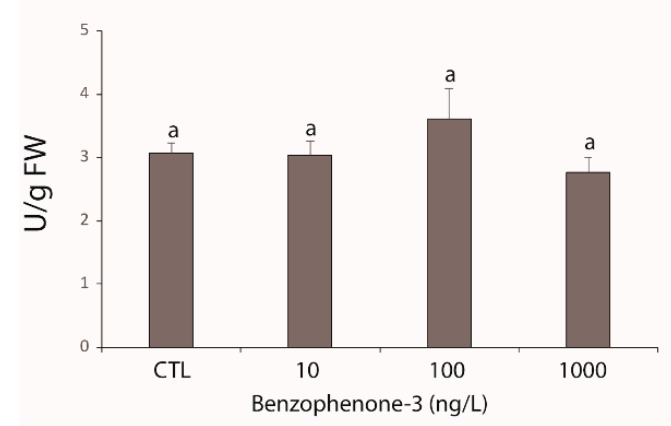

B

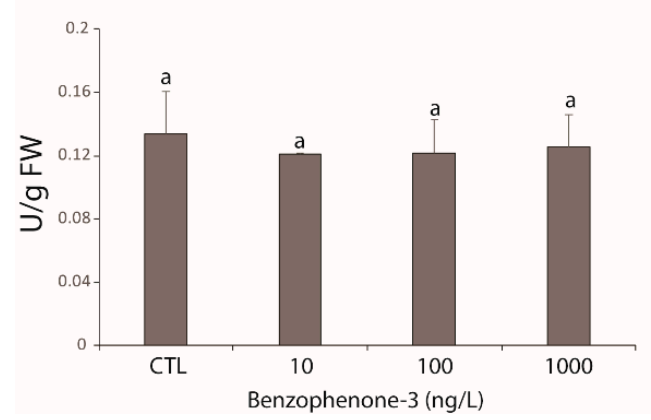

C

GSTs

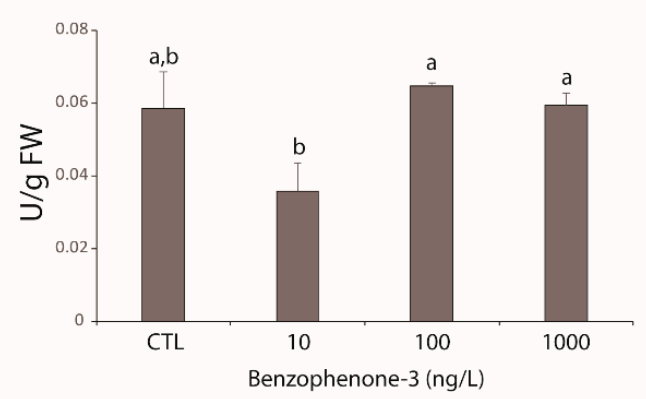

D

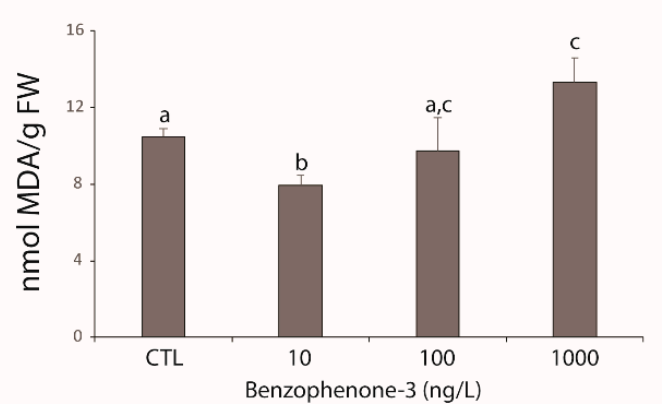

Figure 2. (A): Catalase activity (CAT), (B): glutathione peroxidase activity (GPx), (C): glutathione S-transferases activity (GSTs), (D): lipid peroxidation levels (LPO) in Mytilus galloprovincialis exposed to different concentrations of Benzophenone-3 (CTL-0, 10, 100, and $1000 \mathrm{ng} / \mathrm{L}$ ) for $96 \mathrm{~h}$. Results are means with standard deviation. Different letters represent significant differences $(p<0.05)$ among concentrations.

The activity of GSTs was significantly lower in mussels exposed to $10 \mathrm{ng} / \mathrm{L}$ of BP3 in comparison to mussels exposed to 100 and $1000 \mathrm{ng} / \mathrm{L}$ exposure concentrations. No significant differences were observed between CTL and contaminated mussels (Figure 2C).

LPO levels were significantly higher in mussels exposed to the highest concentration in comparison to CTL and $10 \mathrm{ng} / \mathrm{L}$ exposed mussels. The lowest LPO levels were observed at $10 \mathrm{ng} / \mathrm{L}$ of BP3, with significant differences to the remaining conditions (Figure 2D).

\section{Discussion}

Benzophenone-3 penetrates human skin directly with dermal application of sunscreens [42,43]. This chemical compound may also be absorbed into human organism via consumption of aquatic species that have been exposed to this compound and consequently incorporated it. Different studies already highlighted that organic compounds may be biomagnified along the food web, resulting in 
higher concentrations accumulated by higher trophic levels [44]. In order to study the pharmacokinetics of BP3 in male Sprague Dawley rats, Kadry et al. [45] administrated $100 \mathrm{mg}$ per kg body weight of this compound via oral way. It was observed that BP3 is eliminated through two phases: phase $\alpha$, which takes about $0.88 \mathrm{~h}$ corresponding to absorption, and phase $\beta$, which takes $15.9 \mathrm{~h}$ where elimination occurs. This study revealed that after $5 \mathrm{~min}$ this filter was already incorporated in the bloodstream, having therefore fast chemical absorption in the gastrointestinal tract due to its two aromatic rings, which make this compound more lipophilic, thus binding easily with plasma proteins. Afterwards, BP3 is metabolized and may conjugate with other molecules namely glucuronic acid, originating the oxidative metabolites 2,4-dihydroxybenzophenone (DHB), 2,2'-dihydroxy-4-methoxybenzophenone (DHMB), and 2,3,4-trihydroxybenzophenone (THB). These metabolites and the remaining BP3 may be distributed for several tissues, mainly liver and kidneys or excreted in urine or feces, where BP3 original form is represented by less than 60\% [45-47]. In humans, Wang and Kannan [48] concluded that, as other xenobiotics, BP3 is metabolized at phases I and II by cytochrome P450 enzymatic system, where demethylation is the main route. Nakagawa and Suzuki [49] demonstrated that the incubation of rat hepatocytes with 0.25 to $1.0 \mathrm{mM}$ of BP3 reduced ATP content and led to cellular morphological damage and its metabolites, DHMB and THB, induced the proliferation of human MCF-7 breast cancer cells and generated cytotoxic effects in these cells.

Although the information regarding the effects of UV filters (namely BP3) in humans, the knowledge concerning the toxic effects of $\mathrm{BP} 3$ on marine species is very scarce. A study with the coral species Stylophora pistillata indicated that BP3 is a genotoxic UV filter, with evidences of DNA damages, leading to the disruption of endocrine system and consequently reducing planulae mobility by inducing its ossification [50]. Meng et al. [51] demonstrated that concentrations ranging from 4 to $20 \mu \mathrm{M}$ BP3 affected not only estradiol biosynthesis and sex differentiation of the fish Danio rerio larvae, but also affected endocrine system and upregulated the expression of cytochrome P450 and glutathione metabolism related genes.

Considering the aforementioned studies and the lack of information regarding the impacts of BP3 in marine bivalves, the present study evaluated the effects caused by environmentally relevant concentrations of BP3 in the mussel species Mytilus galloprovincialis, assessing metabolic capacity, energy reserves content and oxidative stress status in organisms exposed to this compound for $96 \mathrm{~h}$. Regarding mussels' metabolic capacity, the results obtained showed a significant enhance of their electron transport system (ETS) activity only at intermediate concentration (100 ng/L), which may indicate that the lowest concentration $(10 \mathrm{ng} / \mathrm{L})$ was not high enough to increase mussels' metabolism, while the highest concentration $(1000 \mathrm{ng} / \mathrm{L})$ was probably too stressful and limited mussels' metabolic capacity. According to Choi et al. [52], the increase of metabolic capacity is usually related to the necessity of energy for defense mechanisms, namely detoxification. The ETS activity is commonly used as a proxy to the measurement of activity levels of macroenzymes metabolized as response to the organism's respiratory requirements, as stated by Fanslow et al. [53]. The response observed in the present study may thus indicate the ineffectiveness of organisms to increase their metabolic capacity at the highest BP3 concentrations or may point to an hormesis behavior, which is interpreted as the biological processes in response to extreme environmental or challenging conditions that occur in organisms leading to improvements at a molecular or cellular level aiming adaptation, making possible their survival and maintenance along the generations [54]. However, especially regarding the hypothesis of hormesis behavior, due to the short exposure period, these results should be considered with precaution and further research should be conducted on this topic.

At higher energy demands, the expenditure of an organism's energy reserves may increase. Patrick et al. [55] reported that GLY is one of the first energy reserves used under stress conditions. Proteins provide essential resources for structural elements although being the last energetic reserves being degraded for the acquisition of energy [56]. Nevertheless, GLY and PROT content may increase if production exceed their use. In fact, in the present study, higher PROT and GLY content at $100 \mathrm{ng} / \mathrm{L}$ of BP3 relatively to CTL may correspond to increased energy production to fuel activation 
of defense mechanisms and, in the case of PROT, can be associated with higher enzymes production. Coppola et al. [57] assessing arsenic $(1 \mathrm{mg} / \mathrm{L})$ effects along with warming $\left(21^{\circ} \mathrm{C}\right)$ and control $\left(17^{\circ} \mathrm{C}\right)$ temperatures, demonstrated that after 14 days of exposure, PROT and GLY levels increased significantly, although ETS did not show any significant differences among treatments and CTL, which can confirm that these organisms may increase the levels GLY and PROT up to certain stress levels. Therefore, the observed higher levels of energy reserves at intermediate concentration may reflect mussels' response to the concentration $100 \mathrm{ng} / \mathrm{L}$ of BP3 by increasing metabolic pathway activity, aiming to obtain enough energy to enhance PROT production, such as antioxidant enzymes, to activate biological defenses. O'Donovan et al. [28] also demonstrated that the acute exposure (7 days) of Scrobicularia plana to $1 \mathrm{mg} / \mathrm{L}$ of microplastics contaminated with $82 \mathrm{ng} / \mathrm{g}$ of BP3 led to a significant increase in PROT reserves in relation to microplastics acting alone.

The exposure to pollutants and endogenous processes, such as electrons transport chain occurring in the mitochondria, may induce greater production of reactive oxygen species (ROS) in organisms, which are responsible for oxidative cellular damage in membranes [58]. In order to minimize these adverse effects triggered by ROS, namely peroxidation of cellular membranes, organisms are able to increase the activity of antioxidant enzymes and scavengers' content, in order to enhance their defense responses [59]. Lipid peroxidation (LPO) is a process characterized by the reaction of ROS with biological membranes, resulting in the oxidative damage of polyunsaturated fatty acids [60]. The present study demonstrated that up to $100 \mathrm{ng} / \mathrm{L}$ of BP3 no cellular damage occurred, indicating lower ROS production due to low exposure concentrations or, on the other hand, high antioxidant capacity that prevent LPO occurrence. However, at $1000 \mathrm{ng} / \mathrm{L}$, LPO was significantly higher than mussels under lower concentrations, indicating that the stress caused at this concentration may have led to an increase of ROS, inducing cellular damage. Several studies assessing the effects of pollutants in bivalves also revealed that LPO only occurred at the highest exposure concentration as a result of low levels of stress induced (normally associated with low exposure concentration) or high antioxidant capacity to eliminate ROS excess. For example, Almeida et al. [61] demonstrated that the acute exposure of the clam species Ruditapes philippinarum to carbamazepine for $96 \mathrm{~h}$ induced significantly higher levels of LPO only at the highest concentration, $9 \mu \mathrm{g} / \mathrm{L}$. Moreover, Liu et al. [62] verified that the clam species Corbicula fluminea exposed to silver nanoparticles for 14 days only had significantly higher LPO levels at the highest concentration $2 \mathrm{mg} / \mathrm{L}$.

Catalase (CAT) is an antioxidant enzyme that promotes the degradation of hydrogen peroxide into water and oxygen. It is able to remove ROS and thus prevent cellular damage when organisms are under stress conditions, increasing its activity levels [63]. Glutathione peroxidase (GPx) enzymes also play an important antioxidant role by catalyzing hydrogen peroxide into water with GSH (reduced glutathione) oxidation, preventing oxidative cellular damage by the removal of free radicals of oxygen that may derive from ROS $[60,64]$. The results obtained here revealed a slight increase in CAT activity at $100 \mathrm{ng} / \mathrm{L}$, which may be associated with higher protein content at this condition, corroborating the hypothesis that increased PROT content was associated with enzymes' production. Nevertheless, in terms of CAT and GPx activity, no significant differences were observed among conditions, which may once again indicate that concentrations tested were not high enough to induce the activity of these enzymes, or other enzymes (not measured here) were activated, and/or the exposure period was not long enough to induce stress in mussels and to activate their antioxidant capacity. O'Donovan et al. [28] showed that the CAT levels in gills of the clam S. plana exposed to $1 \mathrm{mg} / \mathrm{L}$ of microplastics adsorbed with $82 \mathrm{ng} / \mathrm{g}$ of BP3 for two weeks were not significantly different, which is in agreement with the results obtained in the present study, suggesting that the range of BP3 concentrations tested does not affect antioxidant enzymes.

When organisms are exposed to xenobiotics, glutathione S-transferases (GSTs) enzymes may significantly increase their activity, as they are responsible for conjugating toxic chemicals with an endogenous substrate, most likely reduced glutathione (GSH), during phase II of enzymatic detoxification. This promotes ROS removal, which thus protects organisms against them [65]. In the 
present study, GSTs activity observed in mussels exposed to BP3 remained unaltered among conditions that, again, corroborate the hypothesis that concentrations tested were not high enough to induce activation of defense mechanisms or the short exposure period was not enough to activate organism's defenses. These results are in agreement with data from Campos et al. [66], where Chironomus riparius was exposed to the concentrations $0.25,2.5$ and $25 \mathrm{mg} / \mathrm{Kg}$ of BP3 for $48 \mathrm{~h}$ and no alterations on GSTs activity were observed. In this way, higher LPO levels at the highest exposure concentration may be explained by the lack of antioxidant and biotransformation defenses, with CAT, GPx, and GSTs activities remaining unaltered regardless of BP3 concentration and, therefore, with no elimination of ROS and no protection against their detrimental cellular effects. Thus, we can hypothesize that the stress induced was not high enough to increase enzymes activity and for this reason LPO occurred.

\section{Conclusions}

Herein, low BP3 concentrations, that resembled environmental concentrations, revealed to induce low oxidative stress in mussels with no activation of defense mechanisms and the occurrence of cellular damage only at the highest concentration $(1000 \mu \mathrm{g} / \mathrm{L})$. However, alterations on mussels' metabolism and energy reserves were observed at lower concentration $(100 \mu \mathrm{g} / \mathrm{L})$. Nevertheless, overall limited biochemical alterations were observed, which resulted not only from the fact that concentrations were low but also due to short exposure period $(96 \mathrm{~h})$. In some cases, this may not mimic exposure conditions in the field. Therefore, the results reinforced the need for further research on this topic but also the need for the development of more effective sewage treatments with higher removal capacity of these compounds. Considering that bivalve populations are widely exposed to these compounds, especially along sandy beaches, there is an urgent need to further investigate the impacts of UV filters in these organisms. Moreover, because several bivalve species are economically relevant due to their high human consumption, it is imperative to ensure populations sustainability, prevent loss of biodiversity, and guarantee safety for human consumption.

Author Contributions: Conceptualization, R.F. and C.P.; methodology, D.B., Â.A., and C.L.; resources, A.M.V.M.S., C.P., and R.F.; data curation, D.B. and C.L.; writing-original draft preparation, D.B.; writing-review and editing, R.F. and C.P.; supervision, R.F. and C.P.; project administration, A.M.V.M.S. and R.F.; funding acquisition, A.M.V.M.S., R.F., and C.P. All authors have read and agreed to the published version of the manuscript.

Funding: Ângela Almeida benefited from a PhD grant (SFRH/BD/110218/2015) given by the National Funds through the Portuguese Science Foundation (FCT), supported by FSE and Programa Operacional Capital Humano (POCH) and União Europeia. Rosa Freitas was funded by national funds (OE) through FCT (Fundação para a Ciência e a Tecnologia I.P., in the scope of the framework contract foreseen in the numbers 4,5 and 6 of the article 23, of the Decree-Law 57/2016, of August 29, changed by Law 57/2017, of July 19). This work was financially supported by the project BISPECIAl: Bivalves under Polluted Environment and Climate Change (POCI-01-0145-FEDER-028425) funded by FEDER, through COMPETE2020-Programa Operacional Competitividade e Internacionalização (POCI), and by national funds (OE), through FCT/MCTES. Thanks are also due to Integrated Program of SR and TD "Smart Valorization of Endogenous Marine Biological Resources Under a Changing Climate" (reference Centro-01-0145-FEDER-000018), co-funded by Centro 2020 program, Portugal 2020, European Union, through the European Regional Development Fund.

Acknowledgments: Thanks are due to FCT/MCTES for the financial support to CESAM (UIDB/50017/2020+ UIDP/50017/2020).

Conflicts of Interest: The authors declare no conflict of interest.

\section{References}

1. Lodén, M.; Beitner, H.; Gonzalez, H.; Edström, D.W.; Åkerström, U.; Austad, J.; Buraczewska-Norin, I.; Matsson, M.; Wulf, H.C. Sunscreen use: Controversies, challenges and regulatory aspects. Br. J. Dermatol. 2011, 165, 255-262.

2. De Gruijl, F.R. Photocarcinogenesis: UVA vs. UVB Radiation. Ski. Pharmacol. Appl. Ski. Physiol. 2002, 15, 316-320. [CrossRef] [PubMed]

3. Richardson, S.D. Environmental mass spectrometry: Emerging contaminants and current issues. Anal. Chem. 2012, 84, 747-778. [CrossRef] [PubMed] 
4. $\quad$ Balmer, M.E.; Buser, H.R.; Müller, M.D.; Poiger, T. Occurrence of some organic UV filters in wastewater, in surface waters, and in fish from Swiss lakes. Environ. Sci. Technol. 2005, 39, 953-962. [CrossRef] [PubMed]

5. CIR (Cosmetic Ingredient Review). Annual Review of Cosmetic Ingredient Safety Assessments-2002/20031. Int. J. Toxicol. 2005, 24, 1-102. [CrossRef]

6. Coronado, M.; De Haro, H.; Deng, X.; Rempel, M.A.; Lavado, R.; Schlenk, D. Estrogenic activity and reproductive effects of the UV-filter oxybenzone (2-hydroxy-4-methoxyphenyl-methanone) in fish. Aquat. Toxicol. 2008, 90, 182-187. [CrossRef]

7. Ternes, T.A.; Joss, A.; Siegrist, H. Scrutinizing Pharmaceuticals and personal care products in wastewater treatment. Environ. Sci. Technol. 2004, 38, 392A-399A. [CrossRef]

8. Calafat, A.M.; Wong, L.Y.; Ye, X.; Reidy, J.A.; Needham, L.L. Concentrations of the sunscreen agent benzophenone-3 in residents of the United States: National Health and Nutrition Examination Survey 2003-2004. Environ. Health Perspect. 2008, 116, 893-897. [CrossRef]

9. Aminot, Y.; Sayfritz, S.J.; Thomas, K.V.; Godinho, L.; Botteon, E.; Ferrari, F.; Boti, V.; Albanis, T.; Köck-Schulmeyer, M.; Diaz-Cruz, M.S.; et al. Environmental risks associated with contaminants of legacy and emerging concern at European aquaculture areas. Environ. Pollut. 2019, 252, 1301-1310. [CrossRef]

10. O'Malley, E.; O'Brien, J.W.; Verhagen, R.; Mueller, J.F. Annual release of selected UV filters via effluent from wastewater treatment plants in Australia. Chemosphere 2020, 247, 125887. [CrossRef]

11. Ramos, S.; Homem, V.; Alves, A.; Santos, L. A review of organic UV-filters in wastewater treatment plants. Environ. Int. 2016, 86, 24-44. [CrossRef] [PubMed]

12. Schneider, S.L.; Lim, H.W. Review of environmental effects of oxybenzone and other sunscreen active ingredients. J. Am. Acad. Dermatol. 2019, 80, 266-271. [CrossRef] [PubMed]

13. Poiger, T.; Buser, H.R.; Balmer, M.E.; Bergqvist, P.A.; Müller, M.D. Occurrence of UV filter compounds from sunscreens in surface waters: Regional mass balance in two Swiss lakes. Chemosphere 2004, 55, 951-963. [CrossRef] [PubMed]

14. Giokas, D.L.; Sakkas, V.A.; Albanis, T.A. Determination of residues of UV filters in natural waters by solid-phase extraction coupled to liquid chromatography-photodiode array detection and gas chromatography-mass spectrometry. J. Chromatogr. A 2004, 1026, 289-293. [CrossRef]

15. Kim, S.; Choi, K. Occurrences, toxicities, and ecological risks of benzophenone-3, a common component of organic sunscreen products: A mini-review. Environ. Int. 2014, 70, 143-157. [CrossRef]

16. Chisvert, A.; Pascual-Martí, M.C.; Salvador, A. Determination of the UV filters worldwide authorised in sunscreens by high-performance liquid chromatography: Use of cyclodextrins as mobile phase modifier. J. Chromatogr. A 2001, 921, 207-215. [CrossRef]

17. Langford, K.H.; Reid, M.J.; Fjeld, E.; Øxnevad, S.; Thomas, K.V. Environmental occurrence and risk of organic UV filters and stabilizers in multiple matrices in Norway. Environ. Int. 2015, 80,1-7. [CrossRef]

18. Tovar-Sánchez, A.; Sánchez-Quiles, D.; Basterretxea, G.; Benedé, J.L.; Chisvert, A.; Salvador, A.; Moreno-Garrido, I.; Blasco, J. Sunscreen Products as Emerging Pollutants to Coastal Waters. PLoS ONE 2013, $8, \mathrm{e} 65451$.

19. Juliano, C.; Magrini, G.A. Cosmetic ingredients as emerging pollutants of environmental and health concern. A mini-review. Cosmetics 2017, 4, 11. [CrossRef]

20. Livingstone, D.R.; Chipman, J.K.; Lowe, D.M.; Minier, C.; Mitchelmore, C.L.; Moore, M.N.; Peters, L.D.; Pipe, R. Development of biomarkers to detect the effects of organic pollution on aquatic invertebrates: Recent molecular, genotoxic, cellular and immunological studies on the common mussel (Mytilus edulis L.) and other mytilids. Int. J. Environ. Pollut. 2000, 13, 56-91. [CrossRef]

21. Rouane-Hacene, O.; Boutiba, Z.; Belhaouari, B.; Guibbolini-Sabatier, M.E.; Francour, P.; Risso-de Faverney, C. Seasonal assessment of biological indices, bioaccumulation and bioavailability of heavy metals in mussels Mytilus galloprovincialis from Algerian west coast, applied to environmental monitoring. Oceanologia 2015, 57, 362-374. [CrossRef]

22. Vidal-Liñán, L.; Villaverde-de-Sáa, E.; Rodil, R.; Quintana, J.B.; Beiras, R. Bioaccumulation of UV filters in Mytilus galloprovincialis mussel. Chemosphere 2018, 190, 267-271. [CrossRef] [PubMed]

23. He, K.; Timm, A.; Blaney, L. Simultaneous determination of UV-filters and estrogens in aquatic invertebrates by modified quick, easy, cheap, effective, rugged, and safe extraction and liquid chromatography tandem mass spectrometry. J. Chromatogr. A 2017, 1509, 91-101. [CrossRef] [PubMed] 
24. He, K.; Hain, E.; Timm, A.; Tarnowski, M.; Blaney, L. Occurrence of antibiotics, estrogenic hormones, and UV-filters in water, sediment, and oyster tissue from the Chesapeake Bay. Sci. Total Environ. 2019, 650 Pt 2, 3101-3109. [CrossRef]

25. Danovaro, R.; Bongiorni, L.; Corinaldesi, C.; Giovannelli, D.; Damiani, E.; Astolfi, P.; Greci, L.; Pusceddu, A. Sunscreens cause coral bleaching by promoting viral infections. Environ. Health Perspect. 2008, 116, 441-447. [CrossRef]

26. Liu, H.; Sun, P.; Liu, H.; Yang, S.; Wang, L.; Wang, Z. Hepatic oxidative stress biomarker responses in freshwater fish Carassius auratus exposed to four benzophenone UV filters. Ecotoxicol. Environ. Saf. 2015, 119, 116-122. [CrossRef]

27. Kim, S.; Jung, D.; Kho, Y.; Choi, K. Effects of benzophenone-3 exposure on endocrine disruptionand reproduction of Japanese medaka (Oryzias latipes)—A two generation exposure study. Aquat. Toxicol. 2014, 155, 244-252. [CrossRef]

28. O'Donovan, S.; Mestre, N.C.; Abel, S.; Fonseca, T.G.; Carteny, C.C.; Willems, T.; Prinsen, E.; Cormier, B.; Keiter, S.S.; Bebianno, M.J. Effects of the UV filter, oxybenzone, adsorbed to microplastics in the clam Scrobicularia plana. Sci. Total Environ. 2020, 733, 139102. [CrossRef]

29. Zhong, X.; Downs, C.A.; Che, X.; Zhang, Z.; Li, Y.; Liu, B.; Li, Q.; Li, Y.; Gao, H. The toxicological effects of oxybenzone, an active ingredient in sun cream personal care products, on prokaryotic alga Arthrospira sp. and eukaryotic alga Chlorella sp. Aquat. Toxicol. 2019, 216, 105295. [CrossRef]

30. Almeida, S.S.; Rocha, T.L.; Qualhato, G.; Oliveira, L.A.R.; Amaral, C.L.; Conceição, E.C.; Sabóia-Morais, S.M.T.; Bailão, E.F.L.C. Acute exposure to environmentally relevant concentrations of benzophenone-3 induced genotoxicity in Poecilia reticulata. Aquat. Toxicol. 2019, 216, 105293. [CrossRef]

31. Paredes, E.; Perez, S.; Rodil, R.; Quintana, J.B.; Beiras, R. Ecotoxicological evaluation of four UV filters using marine organisms from different trophic levels Isochrysis galbana, Mytilus galloprovincialis, Paracentrotus lividus, and Siriella armata. Chemosphere 2014, 104, 44-50. [CrossRef] [PubMed]

32. King, F.D.; Packard, T.T. Respiration and the respiratory electron transport in marine zooplankton. Limnol. Oceanogr. 1975, 20, 2849-2854. [CrossRef]

33. De Coen, W.M.; Janssen, C.R. The use of biomarkers in Daphnia magna toxicity testing. IV. Cellular energy allocation: A new methodology to assess the energy budget of toxicant-stressed Daphnia populations. J. Aquat. Ecosyst. Stress Recovery 1997, 6, 43-55. [CrossRef]

34. Robinson, H.W.; Hogden, C.G. The biuret reaction in the determination of serum proteins I. A study of the conditions necessary for the production of a stable color which bears a quantitative relationship to the protein concentration. J. Biol. Chem. 1940, 135, 707-725.

35. Dubois, M.; Gilles, K.A.; Hamilton, J.K.; Rebers, P.A.; Smith, F. Calorimetric method for determination of sugars and related substances. Anal. Chem. 1956, 28, 350-356. [CrossRef]

36. Johansson, L.H.; Borg, L.A.H. A spectrophotometric method for determination of catalase activity in small tissue samples. Anal. Biochem. 1988, 174, 331-336. [CrossRef]

37. Carregosa, V.; Velez, C.; Pires, A.; Soares, A.M.V.M.; Figueira, E.; Freitas, R. Physiological and biochemical responses of the polychaete Diopatra neapolitana to organic matter enrichment. Aquat. Toxicol. 2014, 155, 32-42. [CrossRef]

38. Paglia, D.E.; Valentine, W.N. Studies on the quantitative and qualitative characterization of erythrocyte glutathione-peroxidase. J. Lab. Clin. Med. 1967, 70, 158-169.

39. Habig, W.H.; Pabst, M.J.; Jakoby, W.B. Glutathione S-transferases. The first enzymatic step in mercapturic acid formation. J. Biol. Chem. 1974, 249, 7130-7139.

40. Buege, J.A.; Aust, S.D. Microsomal lipid peroxidation. Methods Enzymol. 1978, 52, 302-310.

41. Anderson, M.J.; Gorley, R.N.; Clarke, K.R. PERMANOVA+ for PRIMER: Guide to Software and Statistical Methods; PRIMER-E: Plymouth, UK, 2008.

42. Jiang, R.; Roberts, M.S.; Collins, D.M.; Benson, H.A.E. Absorption of sunscreens across human skin: An evaluation of commercial products for children and adults. Br. J. Clin. Pharmacol. 1999, 48, 635-637. [CrossRef] [PubMed]

43. Janjua, N.R.; Mogensen, B.; Andersson, A.-M.; Petersen, J.H.; Henriksen, M.; Skakkebæk, N.E.; Wulf, H.C. Systemic absorption of the sunscreens benzophenone-3, octyl-methoxycinnamate, and 3-(4-methyl-benzylidene) camphor after whole-body topical application and reproductive hormone levels in humans. J. Investig. Dermatol. 2004, 123, 57-61. [CrossRef] [PubMed] 
44. Kelly, B.C.; Ikonomou, M.G.; Blair, J.D.; Morin, A.E.; Gobas, F.A.P.C. Food Web-Specific Biomagnification of Persistent Organic Pollutants. Science 2007, 317, 236-239. [CrossRef] [PubMed]

45. Kadry, A.M.; Okereke, C.S.; Abdel-Rahman, M.S.; Friedman, M.A.; Davis, R.A. Pharmacokinetics of benzophenone-3 after oral exposure in male rats. J. Appl. Toxicol. 1995, 15, 97-102. [CrossRef]

46. Jeon, H.-K.; Sarma, S.N.; Kim, Y.-J.; Rye, J.-C. Toxicokinetics and metabolisms of benzophenone-type UV filters in rats. Toxicology 2008, 248, 89-95. [CrossRef]

47. Okereke, C.S.; Kadry, A.M.; Abdel-Rahman, M.-S.; Davis, R.A.; Friedman, M.A. Metabolism of benzophenone-3 in Rats. Drug Metab. Dispos. 1993, 21, 788-791.

48. Wang, L.; Kannan, K. Characteristic Profiles of Benzonphenone-3 and its Derivatives in Urine of Children and Adults from the United States and China. Environ. Sci. Technol. 2013, 47, 12532-12538. [CrossRef]

49. Nakagawa, Y.; Suzuki, T. Metabolism of 2-hydroxy-4-methoxybenzophenone in isolated rat hepatocytes and xenoestrogenic effects of its metabolites on MCF-7 human breast cancer cells. Chem.-Biol. Interact. 2002, 139, 115-128. [CrossRef]

50. Downs, C.A.; Kramarsky-Winter, E.; Segal, R.; Fauth, J.; Knutson, S.; Bronstein, O.; Ciner, F.R.; Jeger, R.; Lichtenfeld, Y.; Woodley, C.M.; et al. Toxicopathological effects of the sunscreen UV filter, oxybenzone (benzophenone-3), on coral planulae and cultured primary cells and its environmental contamination in Hawaii and the U.S. Virgin Islands. Arch. Environ. Contam. Toxicol. 2016, 70, 265-288. [CrossRef]

51. Meng, Q.; Yeung, K.; Kwok, M.L.; Chung, C.T.; Hu, X.L.; Chan, K.M. Toxic effects and transcriptome analyses of zebrafish (Danio rerio) larvae exposed to benzophenones. Environ. Pollut. 2020, 265 Pt A, 114857. [CrossRef]

52. Choi, J.; Roche, H.; Caquet, T. Hypoxia, hyperoxia and exposure to potassium dichromate or fenitrothion alter the energy metabolism in Chironomus riparius Mg. (Diptera: Chironomidae larvae). Comp. Biochem. Physiol. Part C 2001, 130, 11-17. [CrossRef]

53. Fanslow, D.L.; Nalepa, T.F.; Johengen, T.H. Seasonal changes in the respiratory electron transport system (ETS) and respiration rate of the zebra mussel, Dreissena polymorpha in Saginaw Bay, Lake Huron. Hydrobiologia 2001, 448, 61-70. [CrossRef]

54. Calabrese, E.J.; Mattson, M.P. How does hormesis impact biology, toxicology, and medicine? NPJ Aging Mech. Dis. 2017, 3, 13. [CrossRef] [PubMed]

55. Patrick, S.; Faury, N.; Goulletquer, P. Seasonal changes in carbohydrate metabolism and its relationship with summer mortality of Pacific oyster Crassostrea gigas (Thunberg) in Marennes-Oléron bay (France). Aquaculture 2006, 252, 328-338. [CrossRef]

56. Dittrich, B. Biochemical composition of the parasitic amphipod Hyperia galba in relation to age and starvation. J. Comp. Physiol. BBiochem. Syst. Environ. Physiol. 1991, 161, 441-449. [CrossRef]

57. Coppola, F.; Almeida, Â.; Henriques, B.; Soares, A.M.V.M.; Figueira, E.; Pereira, E.; Freitas, R. Biochemical responses and accumulation patterns of Mytilus galloprovincialis exposed to thermal stress and Arsenic contamination. Ecotoxicol. Environ. Saf. 2018, 147, 954-962. [CrossRef]

58. Shackelford, R.E.; Kaufmann, W.K.; Paules, R.S. Oxidative stress and cell cycle checkpoint function. Free Radic. Biol. Med. 2000, 28, 1387-1404. [CrossRef]

59. Regoli, F.; Giuliani, M.E. Oxidative pathways of chemical toxicity and oxidative stress biomarkers in marine organisms. Mar. Environ. Res. 2014, 93, 106-117. [CrossRef]

60. Oliveira, M.; Maria, V.L.; Ahmad, I.; Serafim, A.; Bebianno, M.J.; Pacheco, M.; Santos, M.A. Contamination assessment of a coastal lagoon (Ria de Aveiro, Portugal) using defence and damage biochemical indicators in gill of Liza aurata-An integrated biomarker approach. Environ. Pollut. 2009, 157, 959-967. [CrossRef]

61. Almeida, Â.; Calisto, V.; Esteves, V.I.; Schneider, R.J.; Soares, A.M.V.M.; Figueira, E.; Freitas, R. Presence of the pharmaceutical drug carbamazepine in coastal systems: Effects on bivalves. Aquat. Toxicol. 2014, 156, 74-87. [CrossRef]

62. Liu, W.; Zeng, Z.; Chen, A.; Zeng, G.; Xiao, R.; Guo, Z.; Yi, F.; Huang, Z.; He, K.; Hu, L. Toxicity effects of silver nanoparticles on the freshwater bivalve Corbicula fluminea. J. Environ. Chem. Eng. 2018, 6, 4236-4244. [CrossRef]

63. Hao, M.; Liu, R. Molecular mechanism of CAT and SOD activity change under MPA-CdTe quantum dots induced oxidative stress in the mouse primary hepatocytes. Spectrochim. Acta Part A Mol. Biomol. Spectrosc. 2019, 220, 117104. [CrossRef] [PubMed] 
64. Ighodaro, O.M.; Akinloye, O.A. First line defence antioxidants-superoxide dismutase (SOD), catalase (CAT) and glutathione peroxidase (GPX): Their fundamental role in the entire antioxidant defence grid. Alex. J. Med. 2017, 54, 287-293. [CrossRef]

65. Sheenan, D.; Meade, G.; Foley, V.M.; Dowd, C.A. Structure, function and evolution of glutathione transferases: Implications for classification of non-mammalian members of an ancient enzyme superfamily. Biochem. J. 2001, 360, 1-16. [CrossRef]

66. Campos, D.; Gravato, C.; Quintaneiro, C.; Golovko, O.; Žlábek, V.; Soares, M.V.M.; Pestana, J.L.T. Toxicity of organic UV-filters to the aquatic midge Chironomus riparius. Ecotoxicol. Environ. Saf. 2017, 143, 210-216. [CrossRef] 